\title{
Longitudinal variations of noontime thermospheric winds in response to IMF Bz temporal oscillations: broken mean circulation and standing feature
}

Research article

Keywords:

Posted Date: October 18th, 2021

DOI: https://doi.org/10.21203/rs.3.rs-46709/v5

License: (9) This work is licensed under a Creative Commons Attribution 4.0 International License.

Read Full License 


\section{Abstract}

The full text of this preprint has been withdrawn by the authors due to author disagreement with the posting of the preprint. Therefore, the authors do not wish this work to be cited as a reference. Questions should be directed to the corresponding author.

\section{Full Text}

The authors have withdrawn this preprint from Research Square. 